\title{
Microwave-Assisted Synthesis of Lactose Acetates with Antimicrobial, Cytotoxic, and Antiviral Properties
}

\author{
Radka Arabadzhieva ${ }^{1}$, Ivan Ivanov ${ }^{10}$, Nadezhda Petkova ${ }^{1 *}$ (i), Mina Todorova ${ }^{2}$, \\ Yulian Tumbarski $^{3}$ (D), Ivanka Vlaeva ${ }^{4}$ (i), Neli Vilhelmova-Ilieva ${ }^{5}$, Ivanka Nikolova ${ }^{5}$, Lora Simeonova ${ }^{5}$ \\ 1 Department of Organic Chemistry and Inorganic Chemistry, University of Food Technologies, 26 Maritza Blvd., 4002 \\ Plovdiv, Bulgaria, radka_grudeva@outlook.com (R.A.); petkovanadejda@abv.bg (N.P.); ivanov_ivan.1979@yahoo.com \\ (I.I.); \\ 2 Department of Organic Chemistry, Plovdiv University Paisii Hiledarski, 24 Tsar Asen Str., 4000, Plovdiv, Bulgaria; \\ mm_todorova@abv.bg (M.T.); \\ 3 Department of Microbiology, University of Food Technologies, 26 Maritza Blvd., 4002, Plovdiv, Bulgaria; \\ tumbarski@abv.bg (Y.T.); \\ 4 Department of Mathematics and Physics, University of Food Technologies, 26 Maritza Blvd., 4002, Plovdiv, Bulgaria; \\ ivlaeva@yahoo.com (I.V.) \\ 5 Department of Virology, The Stephan Angeloff Institute of Microbiology, Bulgarian Academy of Sciences, 26 G. Bonchev \\ Str., 1113 Sofia, Bulgaria; nelivili@gmail.com (N.V-I.); vanianik@mail.bg (I.N.); losimeonova@gmail.com (L.S.) \\ * Correspondence: petkovanadejda@abv.bg (N.P);
}

Received: 25.10.2021; Revised: 22.11.2021; Accepted: 25.11.2021; Published: 12.12.2021

\begin{abstract}
The task of this study was to perform the "green" synthesis of lactose octaacetate through microwave irradiation and to establish their biological activities. Lactose ester was prepared after microwave-assisted esterification of lactose with acetic anhydride (yield 85-90\%). Lactose octaacetate was characterized by a high degree of acetylation (DS 3.2-3.7). The lactose esters' structure was elucidated by infrared spectroscopy and nuclear magnetic resonance spectroscopy. Lactose octaacetate showed better antifungal activities than antibacterial activities. It possessed slight to moderate antifungal activities against Aspergillus niger ATCC 1015, Penicillium sp., Rhizopus sp., Fusarium moniliforme ATCC 38932. Lactose acetates demonstrated low cytotoxicity against three cell lines: Madin-Darby bovine kidney (MDBK) cells, human epithelial type 2 (HEp-2), and Madin-Darby canine kidney (MDCK) cells. This is the first report for antiviral activity of lactose acetates against herpes simplex virus type 1 (HSV-1), influenza virus A/Panama/2007/99/H3N2 - (IAV/H3N2), PV-1 and Coxsackievirus B1. It was found that this compound showed activity with SI $=2.4$ only against PV-1, but against HSV-1, IAV/H3N2, and Coxsackievirus B1 was inactive. The current study demonstrated the applications of lactose acetates as antimicrobial and antiviral substances in food, pharmaceutical, agricultural and cosmetic preparations.
\end{abstract}

Keywords: lactose octaacetates; microwave irradiation; antimicrobial properties, antiviral activity

(C) 2021 by the authors. This article is an open-access article distributed under the terms and conditions of the Creative Commons Attribution (CC BY) license (https://creativecommons.org/licenses/by/4.0/).

\section{Introduction}

At the end of the 20th century, the 12 principles of Green Chemistry were postulated by Paul Anastas and John Warner. These principles impose new rules on the synthesis and analysis of chemicals. This fact marks the beginning of a new era in which industry and the environment are more linked than ever [1,2].

For an extended time, the chemists believed that substances only reacted once they were in a liquid state or dissolved in an exceedingly solvent [3]. The foremost challenging problem 
faced by the industry has been the employment of solvents. Recently, many efforts have been made to substitute or decrease the use of solvents by using microwaves, and materials that might absorb or adsorb reactants, as perform chemical reactions within microwave irradiation.

In modifying carbohydrates, ultrasonic [4-7] and microwave irradiation [8-11] were successfully used to accelerate the esterification process.

Chemical synthesis under microwave irradiation is an alternate method for preparing chemical compounds without the utilization of any solvents. Microwave irradiation has numerous advantages over the standard method: the speed of the process increases, respectively the reaction time decreases, the high purity final products, absence of solvent, heat loss in the environment can be avoided [12]. Microwaves have wavelengths between 0.01 and 1 meter and operate in a frequency range between 0.3 and $30 \mathrm{GHz}$. They are in the electromagnetic spectrum between infrared waves and radio waves [13]. Unlike conventional heating methods, microwave technology enables to achieve cleaner and more efficient chemical reactions with higher yields. Microwave irradiation in chemistry has become a popular technology exploited in medicinal chemistry, nanotechnology, and biochemical processes [14].

Sugar esters are a class of non-ionic, biocompatible, and biodegradable surfactants. They found application in pharmacy, foods, and cosmetic industries [15]. Lactose [ $\beta$-Dgalactopyranosyl- $(1 \rightarrow 4)$ - $\alpha, \beta$-D-glucopyranose] is a disaccharide, and the main sugar occurs in milk and whey its content reaches about $5 \%$. Whey is a waste product that causes serious environmental concerns. Therefore, the isolation of lactose as a by-product of the dairy industry and its further modification can be converted into added-value products [16]. Its peracetates $\left(1,2,3,6,2\right.$ `3 3 ,4 ,6 $6^{`}$-octa-O-acetyl- $\alpha, \beta$-lactose, 2,3,4,6-tetra-O-acetyl- $\beta$-D-galactopyranosyl$(1 \rightarrow 4)-1,2,3,6$-tetra-Oacetyl- $\alpha, \beta$-D-glucopyranose, $\beta$-lactose peracetate) is an important intermediate in synthetic carbohydrate chemistry [17]. Lactose octaacetate (peracetylated lactose), know also as 4-O-(2,3,4,6-Tetra-O-acetyl- $\beta$-D-galactopyranosyl)-1,2,3,6-tetra-Oacetyl-D-glucopyranose; Octa-O-acetyl-D-lactose; $\quad 4-\mathrm{O}-(2,3,4,6-\mathrm{Tetra}-\mathrm{O}$-acetyl- $\beta$-Dgalactopyranosyl)-1,2,3,6-tetra-O-acetyl-D-glucopyranose can be obtained after esterification with acetic anhydride with anhydrous sodium acetate as a catalyst [18-21] with or without solvent [21, 22] at room temperature [20], at $50-60^{\circ} \mathrm{C}$ [21], boiling, or under microwave heating $[18,19,22]$. Lactose acetates were applied as intermediates for glycosyl azides in the presence of a variety of Lewis acids $\left(\mathrm{SnCl}_{4}, \mathrm{TiCl}_{4}, \mathrm{BF}_{3} . \mathrm{OEt}_{2}, \mathrm{TMSOT}_{\mathrm{f}}\right)$. They are also intermediates for an anomeric azidation of per-O-acetylated [23], for aminoethyl glycosides of cell-surface carbohydrates [24], or transesterification [22].

However, some of lactose acetate's functional properties and biological activity have not been revealed and studied in detail yet. Therefore, the microwave-assisted synthesis of lactose esters with acetic anhydride with specific functional characteristics remains challenging. This study aimed at a "green "synthesis of lactose octaacetate by microwave irradiation and to establish its functional characteristics, antimicrobial and antifungal properties, and cytotoxicity, and antiviral activities.

\section{Materials and Methods}

\subsection{Materials.}

All reagents were purchased from Sigma Aldrich (Germany), and they were used as received. Synthesis of lactose octaacetate was conducted using $\mathrm{D}(+)$-lactose monohydrate (Fluka Biochemica, Steinheim), acetic anhydride (Sigma Aldrich, USA), anhydrous sodium 
acetate (Merck, Germany), and 95\% (v/v) ethanol (Merck, Germany) for recrystallization of esters.

\subsection{Synthesis and characterization of lactose acetates.}

\subsubsection{Synthesis of lactose octaacetate.}

Octa-O-acetyl-D-lactose was synthesized as $10.0 \mathrm{~g}(0.029 \mathrm{~mol})$ D-(+)-lactose monohydrate was mixed with $30 \mathrm{~cm}^{3}(0.27 \mathrm{~mol})$ acetic anhydride in a round-bottom flask with $3.0 \mathrm{~g}(0.036 \mathrm{~mol})$. Sodium acetate was used as a catalyst, and the reaction was performed under microwave irradiation ( $700 \mathrm{~W}$ for 10, 15, 20, and 30 minutes) (Scheme 1). The sample was then poured into $200 \mathrm{~cm}^{3}$ distilled water with ice cubes, stirred, and left at $4{ }^{\circ} \mathrm{C}$ for 12 hours. Lactose ester was precipitated as a white solid. Then the lactose ester was filtered under vacuum, and a clean-up procedure was performed with washing with distilled water. Lactose acetate was further purified by recrystallizing with $95 \%$ ethanol and then distilled water. Lactose acetate was dried in a vacuum oven to the constant weight. The lactose octaacetate was further characterized.

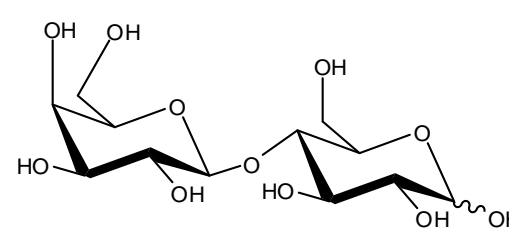

lactose

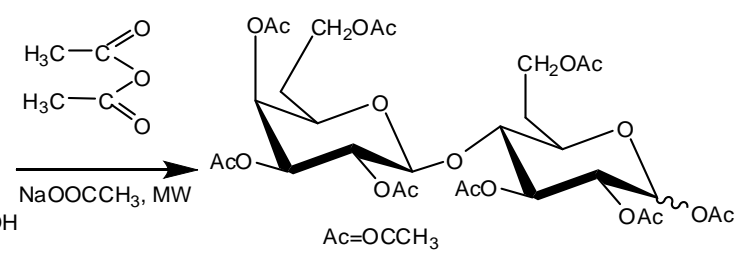

lactose octaacetate

Scheme 1. One-pot synthesis of lactose octaacetate under microwave irradiation.

2.2.2. Melting point.

Melting points of lactose esters were measured with a Kofler hot stage microscope (Reichert, Austria).

\subsubsection{Degree of substitution.}

The percentage of acetylation (\%) and the degree of substitution (DS) were determined by titration [25]. Octa-O-acetyl-D-lactose $(0.5 \mathrm{~g})$ was weighed in a $100 \mathrm{~mL}$ flask, and $30 \mathrm{~mL}$ of $75 \% \mathrm{v} / \mathrm{v}$ ethanol was added. The sample was stirred on a magnetic stirrer for 15 minutes. Then was added $25 \mathrm{~mL} 0.5 \mathrm{M} \mathrm{KOH}$ and the sample was stirred on a magnetic stirrer for 2 hours. The excess of alkali was back-titrated with $0.5 \mathrm{~mol} / \mathrm{L} \mathrm{HCl}$ using indicator phenolphthalein. The blank samples and duplicates were analyzed similarly. The acetyl percentage was calculated.

\subsubsection{Angle of optical rotation.}

The optical rotation of $0.01 \%$ methanol solutions of lactose octaacetate was determined on an automated polarimeter in a tube $1 \mathrm{dm}$ long with a volume of $10 \mathrm{~mL}$ using a sodium lamp as a light source. 
2.2.5. Thin-layer chromatography (TLC).

The thin-layer chromatography was performed on a silica gel Kieselgel $60 \mathrm{~F}_{254}$ plates (Merck, Germany) with eluent with composition ethyl acetate/methanol/water 17:2:1 (v/v/v). The spots appeared after spraying the plates with $10 \%$ (v/v) $\mathrm{H}_{2} \mathrm{SO}_{4}$ methanol solution. The spots were detected after heating in an oven at $120{ }^{\circ} \mathrm{C}$ for $5 \mathrm{~min}$ [26].

\subsubsection{UV spectroscopy.}

Lactose acetates in concentration $1 \mathrm{mg} / \mathrm{mL}$ were prepared in the solvents with different polarities: methanol, ethanol, acetonitrile, dimethylformamide (DMFA), and dimethyl sulfoxide (DMSO). The UV spectra were collected on a UV-30 SCAN spectrophotometer in the wavelength range from 190-400 $\mathrm{nm}[10]$.

\subsubsection{FT-IR spectroscopy.}

The infrared spectra were recorded in $\mathrm{KBr}$ pellets on a Nicolet FT-IR Avatar Nicolet (Thermo Scientific, USA) spectrometer. The absorption was reported in wavenumbers $\left(\mathrm{cm}^{-1}\right)$ in the frequency range of $4000-400 \mathrm{~cm}^{-1}$. Each spectrum was recorded after 132 scans.

\subsubsection{Nuclear magnetic resonance spectroscopy (NMR).}

The ${ }^{1} \mathrm{H}$ and ${ }^{13} \mathrm{C}$ NMR spectra of Octa-O-acetyl-D-lactose were recorded on a Bruker Advance III $500 \mathrm{MHz}$ spectrometer (Bruker BioSpin, Wissembourg, France) operating at 151 $\mathrm{MHz}$ using $\mathrm{CDCl}_{3}$. Lactose acetate $\left(20 \mathrm{mg}\right.$ ) was dissolved in $0.6 \mathrm{~mL} \mathrm{CDCl}_{3}$, as a solvent, and spectra were collected. All chemical shifts were reported in ppm with reference to TMS.

${ }^{l} \mathrm{H}$ NMR $\left(500 \mathrm{MHz}, \mathrm{CDCl}_{3}\right) \delta 5.62-5.41(\mathrm{~m}, 3 \mathrm{H}), 5.08(\mathrm{dd}, \mathrm{J}=39.8,18.8 \mathrm{~Hz}, 7 \mathrm{H})$, $5.04(\mathrm{~d}, \mathrm{~J}=9.7 \mathrm{~Hz}, 2 \mathrm{H}), 4.86$ (dddd, $\mathrm{J}=46.1,36.3,16.8,8.2 \mathrm{~Hz}, 18 \mathrm{H}), 4.49$ (ddd, J = 61.7, $46.4,8.1 \mathrm{~Hz}, 6 \mathrm{H}), 4.20$ (d, J = 10.9 Hz, 3H), 4.06 (d, J = $11.0 \mathrm{~Hz}, 5 \mathrm{H}), 3.98-3.80(\mathrm{~m}, 20 \mathrm{H})$, $3.81(\mathrm{~d}, \mathrm{~J}=7.7 \mathrm{~Hz}, 4 \mathrm{H}), 4.32-2.82(\mathrm{~m}, 55 \mathrm{H}), 4.32-2.82(\mathrm{~m}, 55 \mathrm{H}), 3.84-3.41(\mathrm{~m}, 21 \mathrm{H})$, $3.40(\mathrm{~s}, 2 \mathrm{H}), 2.64-0.29(\mathrm{~m}, 128 \mathrm{H})$.

${ }^{13} \mathrm{C} \mathrm{NMR}\left(126 \mathrm{MHz}, \mathrm{CDCl}_{3}\right) \delta 173.22,170.87,170.58,170.45,170.29,170.25,170.19$, $170.05,169.99,169.86,169.77,169.55,169.36,169.31,168.95,168.91,101.53$ (C1 $\beta$-DGalp), 100.74 (C1 $\beta$-D-Galp), 100.52 (C1 $\alpha$-Glc) 91.30, 81.50, 77.67, 77.41, 77.16, 75.41, 73.12, 72.82, 72.36, 72.24, 71.22, 71.10, 70.71, 70.61, 70.38, 70.29, 69.45, 68.85, 68.52, 66.85, $66.75,62.21,61.66,60.96,20.44,20.40,20.35,20.29,20.22,20.13,20.06$.

\subsection{Functional properties of lactose acetates.}

\subsubsection{Swelling properties.}

The swelling properties of lactose acetates were evaluated [27]. Lactose acetates (100 $\mathrm{mg}$ ) were hydrated with $10 \mathrm{~mL}$ of distilled water in a calibrated cylinder at $25^{\circ} \mathrm{C}$. After an 18 $\mathrm{h}$ equilibration, the bed volume was recorded and expressed as an $\mathrm{mL} / \mathrm{g}$ sample.

\subsubsection{Water holding capacity (WHC) and oil holding capacity (OHC).}

The WHC and OHC of lactose acetates were evaluated in duplicate [28]. Lactose acetate (LA $10 \mathrm{~s})(0.10 \mathrm{~g})$ was added into a pre-weighed $50 \mathrm{~mL}$ centrifuge tube. Then $10 \mathrm{~mL}$ of deionized water or sunflower oil was added, respectively. After $12 \mathrm{~h}$ at $25^{\circ} \mathrm{C}$, the sample 
was centrifuged at $3500 \mathrm{rpm}$ for $15 \mathrm{~min}$. The excess water and oil were discarded. The tubes were weighed and dried at $105^{\circ} \mathrm{C}$ to the constant weight.

\subsubsection{Foam stability (FS) and foamability (FA).}

FS and FA of lactose acetates were also evaluated as all experiments were performed in triplicate [29]. The aqueous dispersion of lactose acetates $(20 \mathrm{~mL})$ in $0.01 \%$ concentrations was placed in $50 \mathrm{~mL}$ stoppered graduated cylinders, and the initial height of each solution was checked. The solution was vigorously shaken for $1 \mathrm{~min}$, and the foam height and the total height were measured in cm immediately. The foam heights at 1, 2, 3, 5, 10, 20, 30, and 60 min were recorded at $25^{\circ} \mathrm{C}$.

\section{Antimicrobial activity.}

\subsection{Test microorganisms.}

Eight Gram-positive bacteria (Bacillus subtilis ATCC 6633, Bacillus cereus, Bacillus amyloliquefaciens strain 4BCL-YT, Staphylococcus aureus ATCC 25923, Listeria monocytogenes ATCC 8632, Enterococcus faecalis, Micrococcus luteus strain 2YC-YT, Curtobacterium flaccumfaciens strain PM-YT), five Gram-negative bacteria (Salmonella enteritidis, Klebsiella sp., Escherichia coli ATCC 8739, Proteus vulgaris ATCC 6380, Pseudomonas aeruginosa ATCC 9027), yeasts (Candida albicans NBIMCC 74, Saccharomyces cerevisiae), and fungi (Aspergillus niger ATCC 1015, Aspergillus flavus, Penicillium sp., Rhizopus sp., Fusarium moniliforme ATCC 38932) from the collection of the Department of Microbiology at the University of Food Technologies, Plovdiv, Bulgaria, were selected for the antimicrobial test. The concentration of the viable cells and spores in the suspensions for inoculation was adjusted to $1.0 \cdot 10^{5} \mathrm{CFU} \mathrm{mL}$ (for fungal spores) and 1.0 $10^{9}$ CFU mL (for bacterial and yeast cells).

\subsection{Culture media.}

For the cultivation of the Gram-positive bacteria, Gram-negative bacteria, and yeasts were used Luria-Bertani glucose agar medium (LBG agar medium) prepared as previously described [30].

Malt extract agar (MEA) was used to cultivate the fungi. This media has consisted of $20 \mathrm{~g}$ malt extract, $20 \mathrm{~g}$ dextrose, $6 \mathrm{~g}$ peptone, and $15 \mathrm{~g}$ agar dissolved in $1 \mathrm{~L}$ of deionized water. The final $\mathrm{pH}$ was corrected to 5.5; the medium was sterilized by autoclaving at $121^{\circ} \mathrm{C}$ for 20 $\min$.

\subsection{Antimicrobial assay.}

Methanol and DMSO were used as solvents to prepare the desired solutions $10 \mathrm{mg} / \mathrm{mL}$ of lactose acetate. The antimicrobial activity of samples was determined using the agar well diffusion method [30].

Lactose acetates and controls $(60 \mu \mathrm{L})$ were placed into the agar wells in triplicates. Methanol and DMSO were used as controls, as positive controls were used Streptomycin, Ampicillin, and Nystatin. The antimicrobial activity of lactose acetates was evaluated by the diameter of the inhibition zones around the wells on the 24th and the 48th hour of incubation. The inhibition zones of $18 \mathrm{~mm}$ or more were listed as sensitive (strong inhibitory effect); with 
zones from 12 to $18 \mathrm{~mm}$ - moderate inhibitory effect, with the inhibition zones up to $12 \mathrm{~mm}$ or completely missing -insignificant or low inhibitory effect.

\section{Cytotoxic and antiviral activity.}

\subsection{Cells.}

Madin-Darby bovine kidney (MDBK) cells and Human epithelial type 2 (HEp-2) cells from human laryngeal carcinoma were obtained from National Bank for Industrial Microorganisms and Cell Cultures, Sofia. Madin-Darby canine kidney MDCK cells (NBL-2; CCL-34) were purchased from ATCC, Manassas, USA. The three cell lines were grown in DMEM medium containing 10\% fetal bovine serum (FBS) (Gibco BRL, USA), with $10 \mathrm{mM}$ HEPES buffer (Merck, Germany) and antibiotics (penicillin $100 \mathrm{IU} / \mathrm{mL}$, streptomycin 100 $\mu \mathrm{g} / \mathrm{mL}$ ) in a $\mathrm{CO}_{2}$ incubator (HERA cell 150 , Heraeus, Germany) at $37^{\circ} \mathrm{C} / 5 \% \mathrm{CO}_{2}$.

\subsection{Viruses.}

Most of the viruses, except Herpes simplex virus type 1 (HSV-1), used in the current research, were collected from the Stephan Angeloff Institute of Microbiology, BAS (Sofia, Bulgaria). Only Herpes simplex virus type 1 (HSV-1), Victoria strain was the National Center of Infectious and Parasitic Diseases, Sofia.

Coxsackieviris B1 (Connecticut 5 strain, CVB1) was propagated in HEp-2 cells (maintenance solution DMEM (Gibco, BRL) with $10 \mathrm{mmol} / \mathrm{l}$ HEPES, 0,5\% FBS, penicillin $100 \mathrm{IU} / \mathrm{mL}$ and streptomycin $100 \mathrm{mg} / \mathrm{mL}$ ); infectious titer - $106.5 \mathrm{CCID} 50 / \mathrm{mL}$.

PV-1 (strain LSc-2ab) was replicated in HEp-2 cells (maintenance solution DMEM (Gibco, BRL) with $10 \mathrm{mmol} / \mathrm{l} \mathrm{HEPES,} \mathrm{0.5 \%} \mathrm{FBS,} \mathrm{penicillin} 100 \mathrm{IU} / \mathrm{mL}$ and streptomycin 100 $\mathrm{mg} / \mathrm{mL}$ ); infectious titer - $107 \mathrm{CCID} 50 / \mathrm{mL}$.

Herpes simplex virus type 1(HSV-1) virus was reproduced in monolayer MDBK cells in a maintenance solution DMEM Gibco BRL, Paisley, Scotland, UK, plus 0.5\% FBS. An infectious titer of stock virus was 107 CCID50/mL.

Influenza virus A/Panama/2007/99/H3N2 - (IAV/H3N2) was obtained from allantoic fluids of virus-inoculated 10-days-embryonated eggs, incubated at $37^{\circ} \mathrm{C}$; infectious virus titer determined as $106.0 \mathrm{CCID} 50 / \mathrm{mL}$.

\subsection{Cytotoxicity assay.}

Confluent monolayer cell cultures MDBK, HEp-2, or MDCK in a 96-well plate was treated with a culture medium containing no (untreated control) or increased concentrations of the compounds. The cells were incubated at $37^{\circ} \mathrm{C}$ and $5 \% \mathrm{CO}_{2}$ for $48 \mathrm{~h}$. After drug treatment, the viability of the cells was measured using a neutral red uptake assay and ELISA reader at wavelength $540 \mathrm{~nm}$.

\subsection{Antiviral activity assay.}

Cytopathic effect (CPE) inhibition test was performed and was calculated, as previously described [31]. The 50\% inhibitory concentration $\left(\mathrm{IC}_{50}\right)$ was defined as the concentration inhibited $50 \%$ of viral replication compared to the virus control. The selectivity index (SI) was calculated from the ratio $\mathrm{CC} 50 / \mathrm{IC}_{50}$. 
4.5. Virucidal assay.

The contact samples of $1 \mathrm{~mL}$ containing HSV-1 (105 CCID50) and tested compounds in their maximal tolerate concentration (MTC) in a 1:1 ratio. The samples were stored at room temperature for different time intervals $(15,30,60,90$, and $120 \mathrm{~min})$. Then, the infectious viral titer of all samples was determined by endpoint dilution titration. The results were compared to those from virus control - an equal volume of virus suspension and maintenance medium, incubated for the same time intervals, and $\Delta \log$ was calculated.

\subsection{Virus attachment assay.}

The cell monolayers of MDBK, or HEp-2 cells in 24-well cell culture plates (pre-chilled at $4^{\circ} \mathrm{C}$ ) were inoculated with $104 \mathrm{CCID} 50$ of HSV-1, CBV1, or PV-1 at $4^{\circ} \mathrm{C}$ and treated in parallel with maximal tolerate concentration (MTC) of the compounds [31].

\subsection{Pretreatment of MDBK cells.}

Monolayers of MDBK cells in 24-well cell culture plates (CELLSTAR, Greiner BioOne) $\left(2 \times 10^{6}\right.$ cells per well $)$ were tested for $15,30,60,90$, and $120 \mathrm{~min}$ at a concentration of MTC of lactose octaacetate, according to the procedure [31]. The results were compared to those from virus control - cells infected with the virus but not pre-treated with the extract. Then $\Delta \operatorname{logs}$ were determined.

\section{Results and Discussion}

\subsection{Synthesis and characterization of lactose acetates.}

The results from the microwave-assisted synthesis of lactose esters are summarized in Table 1. Moreover, the results from the green method of synthesis were compared with conventional acetylation. All lactose esters present white to faint yellow powder substances slightly bitter taste. Bitter tastes for sugar acetates were also reported [32-34]. In our previous studies, the bitter taste was reported for sucrose and inulin acetates $[4,10]$. The full substitution of hydroxyl groups and its modification in acetyl esters alter sweet sugar to bitter acetyl derivatives.

Table 1. Characterization of lactose acetates with molar ratio (1:10:5).

\begin{tabular}{l|l|l|l|l|l|l}
$\begin{array}{l}\text { Sampl } \\
\mathbf{e}\end{array}$ & Conditions & $\begin{array}{l}\text { Time, } \\
\mathbf{m i n}\end{array}$ & $\begin{array}{l}\text { Yield, } \\
\mathbf{\%}\end{array}$ & $\begin{array}{l}\text { Melting } \\
\text { point, }{ }^{\circ} \mathbf{C}\end{array}$ & $\begin{array}{c}{[\boldsymbol{\alpha}]_{\boldsymbol{D}}^{\mathbf{2 5}}} \\
\left(\mathbf{c = 0 . 0 1 ,} \mathbf{C H}_{\mathbf{3}} \mathbf{O H}\right)\end{array}$ & $\begin{array}{l}\text { Degree } \\
\text { substitution }\end{array}$ \\
\hline LA 1 & Microwave irradiation, 700 W & 10 & 78 & $89.8-90.8$ & -28 & 3.71 \\
\hline LA 2 & Microwave irradiation, 700 W & 15 & 91 & $90.1-91.1$ & -27 & 3.27 \\
\hline LA 3 & Microwave irradiation, 700 W & 20 & 91 & $89.9-90.9$ & -27 & 3.21 \\
\hline LA 4 & Microwave irradiation, 700 W & 30 & 39 & $93.8-94.8$ & -28 & 3.54 \\
\hline LA C & Conventional & 60 & 85 & $90.5-91.5$ & -27 & 3.37
\end{tabular}

The highest yield (91\%) was obtained for 15-20 min with microwave-assisted irradiation. In our study, the yield of lactose octatacetates was higher than reported yields using iodine, pyridine, $\mathrm{FeCl}_{3}$ [22] and comparable with Patil et al. [18] for $25 \mathrm{sec}$ at $\mathrm{MW}$ conditions (Yield 75-89\%). Moreover, the acetylation of 50\% was obtained only for $10 \mathrm{~min}$, which reveals the advantage of microwave irradiation. It reduces acetylation time more than 5 times as yield remains constant compared to conventional esterification. The melting points of lactose acetates were in the range of $89-91.5^{\circ} \mathrm{C}$. The substitution of hydroxyl groups with acetyl 
residues lowers the melting point of lactose esters. Similar trends were observed in other studies for acetates of lactose, sucrose, and inulin $[4,10,18,34]$ - optical rotation changes from $+52.3^{\circ}$ for lactose to negative values (Table 1). A negative angle of optical rotation but with smaller values was also reported in the literature [18].

The quantitative analysis of lactose esters was performed by TLC analysis (Figure 1). The results showed that all lactose esters had $R_{f}=0.74$, which was comparable with those of other sugar esters - sucrooctaacetate $R_{\mathrm{f}}=0.76$.

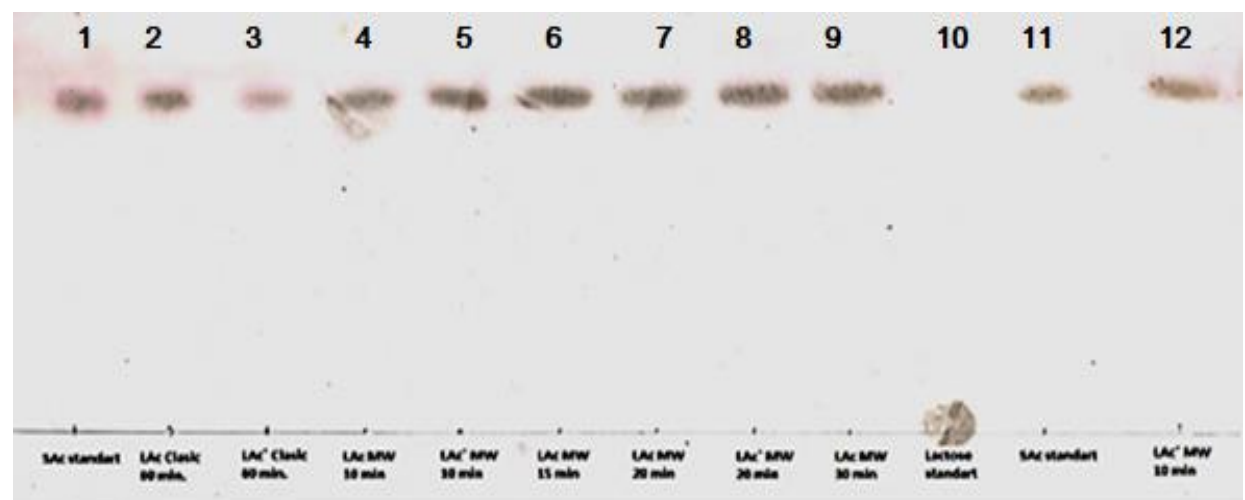

Figure 1. TLC chromatograms of lactose acetates synthesized under different conditions, where 1. SAcsucrooctaacetate (standard), 10. lactose and 2-12. lactose octaacetate in ethyl acetate/methanol/water 17:2:1 (v/v/v) as mobile phase and $10 \% \mathrm{H}_{2} \mathrm{SO}_{4}$ as a detecting reagent.

\subsection{UV Spectroscopy.}

In Figure 2, the UV spectra of lactose acetates were presented in the wavelengths range from 190 to $400 \mathrm{~nm}$. The absorption properties of investigation compounds in different polarity solvents (methanol, ethanol, acetonitriledioxane, dimethylformamide, dimethyl sulfoxide, etc.) were summarized in Table 2 .

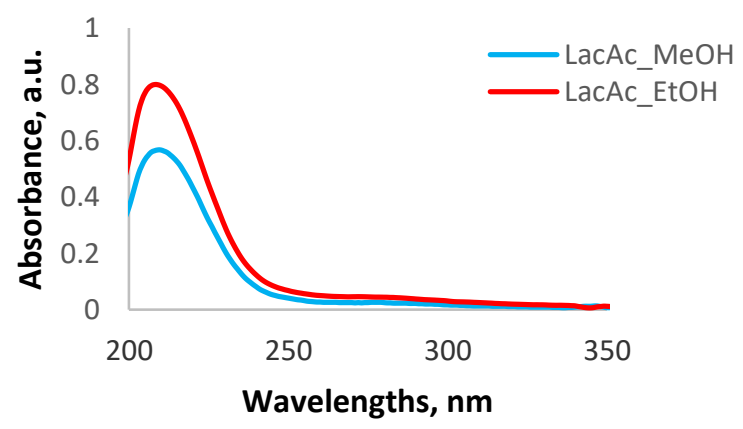

A)

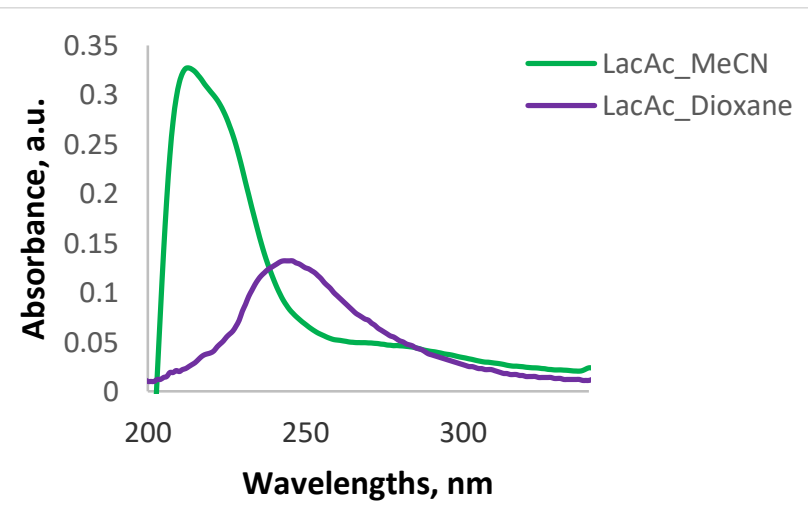

B) 


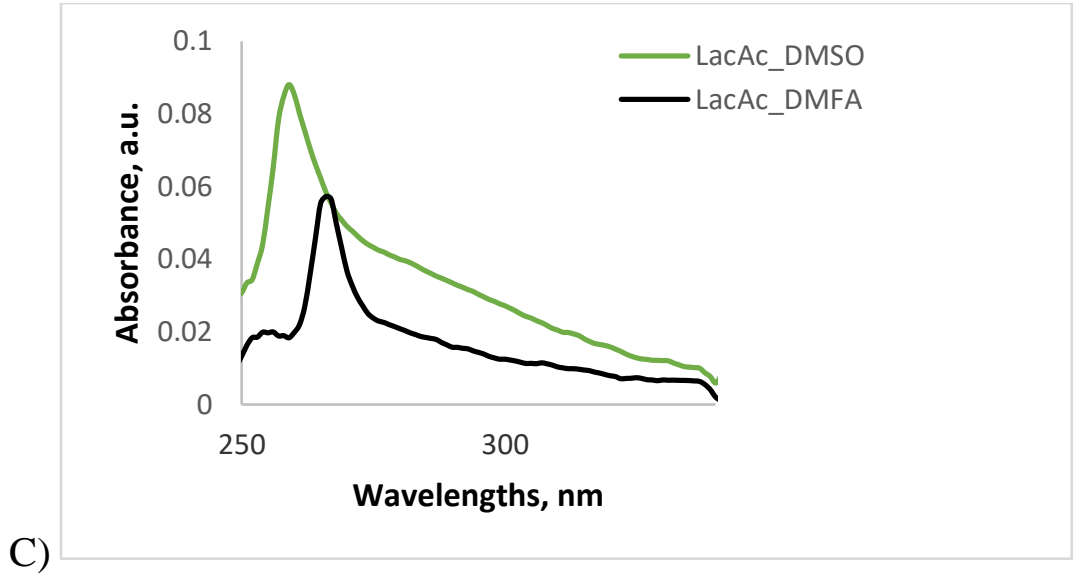

Figure 2. UV spectra of lactose octaacetate $(1 \mathrm{mg} / \mathrm{mL})$ in different solvents: $\mathbf{A})$ methanol and absolute ethanol, B) acetonitrile and dioxane, C) N,N-dimethylformamide (DMFA), and dimethyl sulfoxide (DMSO).

Table 2. The absorption properties of lactose octaacetate in different solvents.

\begin{tabular}{|c|c|c|c|c|c|}
\hline & & $\begin{array}{l}\text { Polarity index } \\
{[35]}\end{array}$ & $\begin{array}{l}\Delta F,\left(\varepsilon, n^{2}\right) \\
{[36]}\end{array}$ & $\lambda_{\max }(\mathbf{A})(\mathbf{n m})$ & $\varepsilon,\left(\mathrm{L} \cdot \mathrm{mol}^{-1} \cdot \mathrm{cm}^{-1}\right)$ \\
\hline \multirow[t]{2}{*}{ № } & Solvents & & & & \\
\hline & \multicolumn{5}{|c|}{ Proton donating solvents } \\
\hline 1. & Methanol & 5.1 & 0.2887 & 209 & 0.5670 \\
\hline \multirow[t]{2}{*}{2.} & Ethanol & 5.2 & 0.1548 & 208 & 0.7991 \\
\hline & \multicolumn{5}{|c|}{ Proton accepting solvents } \\
\hline 3. & Dioxane & 4.8 & 0.0204 & 245 & 0.1320 \\
\hline 4. & Acetonitrile & 5.8 & 0.3045 & $\begin{array}{l}213 \\
221 \text { shoulder }\end{array}$ & $\begin{array}{l}0.3272 \\
0.2991 \\
\end{array}$ \\
\hline 5. & DMFA & 6.4 & 0.2743 & 266 & 0.0572 \\
\hline 6. & DMSO & 7.2 & 0.2634 & 259 & 0.0880 \\
\hline
\end{tabular}

The absorption maximum in both protons donating solvents methanol and ethanol was detected at $209 \mathrm{~nm}$ and $210 \mathrm{~nm}$, respectively. In the acetonitrile spectrum of lactose acetates, the maximum absorption band was found at $213 \mathrm{~nm}$ with a shoulder at $221 \mathrm{~nm}$. Stagner et al. [34] reported an absorption maximum of sucrose octaacetate in mixed solvent acetonitrilewater (30:70) at $210 \mathrm{~nm}$. In solvent 1,4-dioxane the absorption maximum was observed at 245 $\mathrm{nm}$ and DMF and DMSO - at $266 \mathrm{~nm}$ and $259 \mathrm{~nm}$, respectively. Petkova et al. [10] investigated inulin acetate esters and reported absorption maxima in solvents $\mathrm{N}, \mathrm{N}$-dimethylformamide, and dimethylsulfoxide at $266 \mathrm{~nm}$ and $257.5 \mathrm{~nm}$, respectively. This is the first study where the absorption maximum of lactose octaacetates was evaluated.

\subsection{FT-IR spectroscopy.}

FT-IR spectroscopy octa-O-acetyl-D-lactose synthesized by microwave irradiation was used to identify functional groups. Acetylation of lactose was confirmed by FTIR spectra (Figure 3).

The broadband at $3320 \mathrm{~cm}^{-1}$ typical for the stretching vibrations of free $\mathrm{OH}$ groups in lactose were not observed after esterification. This is due to the fact that $\mathrm{OH}$ was replaced with acetyl $\left(-\mathrm{COCH}_{3}\right)$ residues. In the FTIR spectrum of lactose acetates, a new band at $1752 \mathrm{~cm}^{-1}$ was observed that was due to stretching vibration of $\mathrm{C}=\mathrm{O}$ groups from acetyl ester (Figure 3). New bands also appeared at $1371 \mathrm{~cm}^{-1}$ assigned with the bending of $\mathrm{C}-\mathrm{H}$ from $\mathrm{CH}_{3}$ and $-\mathrm{C}-$ $\mathrm{O}$ stretching. FTIR spectrum of lactose acetate contained other typical bands for lactose at 2985 $\mathrm{cm}^{-1}$ that was assigned to $\mathrm{CH}_{2}$, wagging $\mathrm{CH}_{2}$ at $1436 \mathrm{~cm}^{-1}$, and stretching vibration of $\mathrm{C}-\mathrm{O}$ at $1047 \mathrm{~cm}^{-1}$. In addition, the acetyl $\left(-\mathrm{COCH}_{3}\right)$ groups were also observed at $1220 \mathrm{~cm}^{-1}$. The 
bands at $952 \mathrm{~cm}^{-1}$ confirmed that this ester contained $\beta$-D-galactopyranosyl residues linked by $1 \rightarrow 4$ glycoside bonds. All these findings confirmed the successful acetylation of lactose. Most of the bands were in accordance with reported data for lactose and sucrose acetate $[10,24,37$, 38].

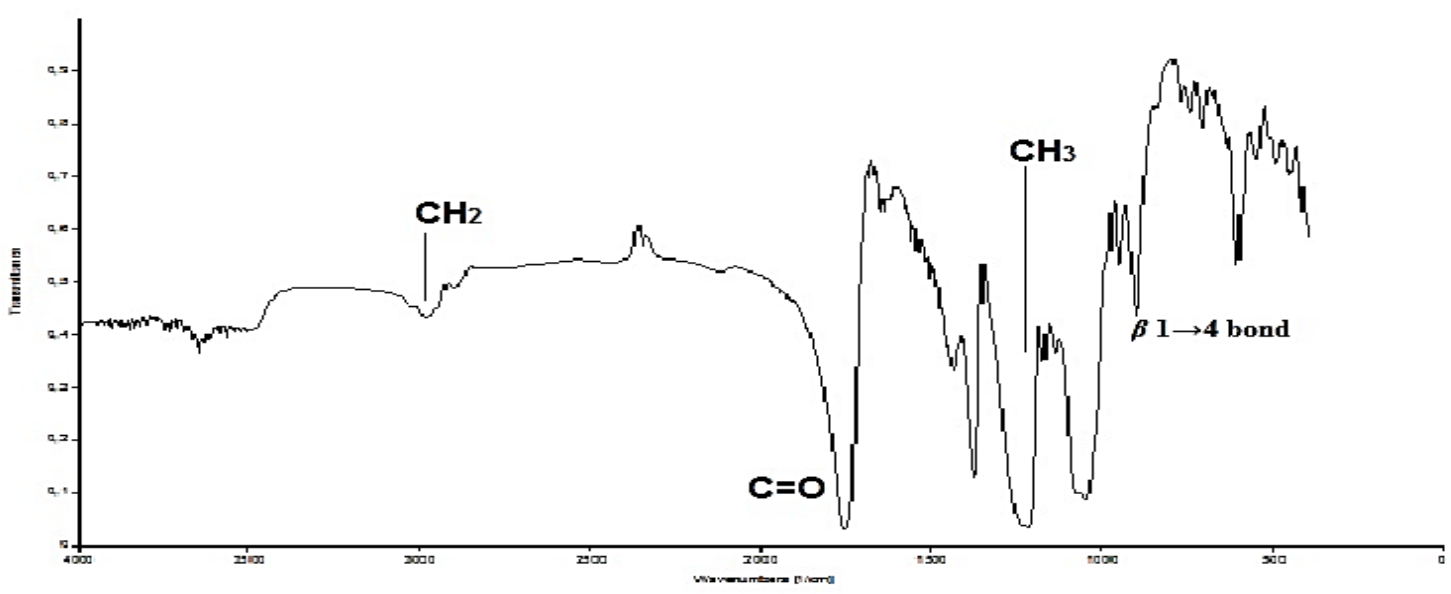

Figure 3. FTIR spectrum of octa-O-acetyl-D-lactose (LA1) synthesized by microwave irradiation.

\subsection{Nuclear magnetic resonance spectroscopy (NMR).}

The NMR spectra approve the structure of obtained lactose esters.

NMR spectra showed that lactose acetates consisted of a mixture of 2,3,4,6-tetra-Oacetyl- $\beta$-D-galactopyranosyl- $(1 \rightarrow 4)-1,2,6$-tri-O-acetyl $\alpha, \beta$-D-glucopyranose, $\alpha: \beta=\sim 1: 2.2$.

${ }^{1} \mathrm{H}$ NMR spectrum of lactose acetate contained chemical shifts typical for a methyl side chain of acetyl groups $\left(\mathrm{COCH}_{3}\right)$ that was found at $\sim 2 \mathrm{ppm}$. Chemical shifts for acetyl carbonyl was observed at $\delta 173.22,170.87,170.58,170.45,170.29,170.25,170.19,170.05,169.99$, $169.86,169.77,169.55,169.36,169.31,168.95,168.91 \mathrm{ppm}$. All the methyl carbons from the acetyl residue appeared at $\delta 20 \mathrm{ppm}\left(\mathrm{COCH}_{3}\right)$. The chemical shifts relevant to carbon atoms of the lactose (glucose and galactose residues) were found in the range of 62.70 to $101.53 \mathrm{ppm}$. The shift at $101.53 \mathrm{ppm}$ typical for $\mathrm{C}_{1}$ from galactose that was involved in the linkage $\beta$ - $(1 \rightarrow 4)$ -D-glucospyranose residue were found in an anomeric region (Figure 4). Similar shifts were reported for lactose acetates synthesized by classical method and microwave methods $[19,25]$. Reported by shifts were near to Peng [19]: ${ }^{13} \mathrm{C} \mathrm{NMR}\left(\mathrm{CDCl}_{3}, \alpha\right.$ anomer): $\delta 101.9$ (C-1II), 89.2 (C-1I ), 82.1 (C-4I ), 71.5 (C-5II), 70.8 (C-3II), 70.5 (C-2I ), 69.6 (C-5I ), 69.5 (C-3I), 68.7 (C2II), 66.8 (C-4II), 62.1 (C-6I ), 61.8 (C-6II); 13C NMR $\left(\mathrm{CDCl}_{3}, \beta\right.$ anomer): $\delta 102.0$ (C-1II), 91.6 (C-1I ), 82.1 (C-4I), 73.3 (C-3I ), 72.6 (C-5I ), 71.5 (C-5II), 71.2 (C-2I), 70.8 (C-3II), 68.6 (C-2II), 66.8 (C-4II), 62.2 (C-6I), 61.8 (C-6II).

\subsection{Functional properties.}

\subsubsection{Swelling properties.}

Lactose acetates demonstrated better swelling properties ( $2.82 \mathrm{~mL}$ water/g sample) in comparison to FOSs acetates $(1.37 \mathrm{~mL}$ water/g sample) and inulin acetates with longer chains $[10,29]$. The number of acetylated hydroxyl groups influenced on swelling properties of carbohydrate acetylated ester. The swelling properties decreased in the following order monosaccharide > oligosaccharide > polysaccharide acetates [19]. 


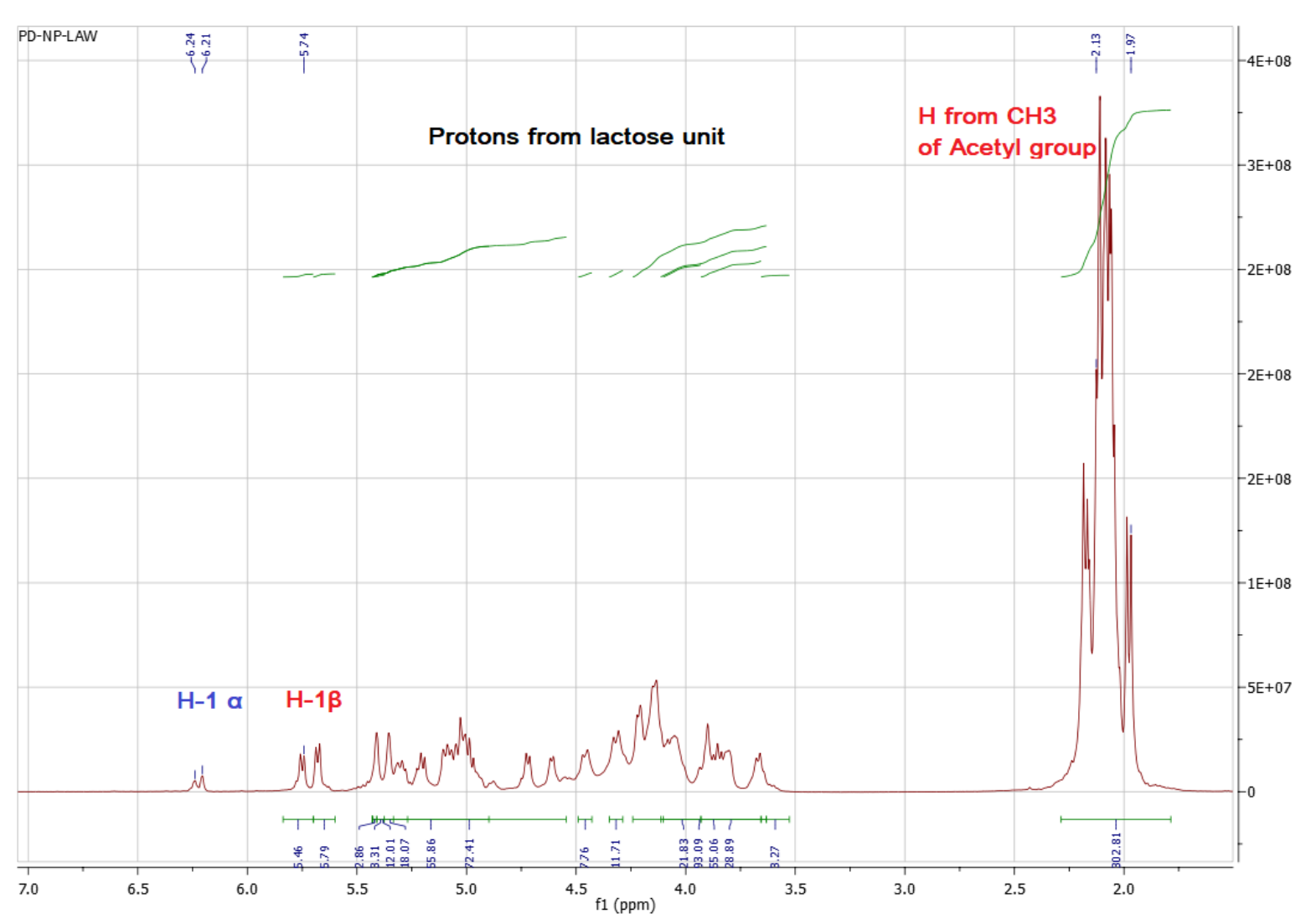

a)

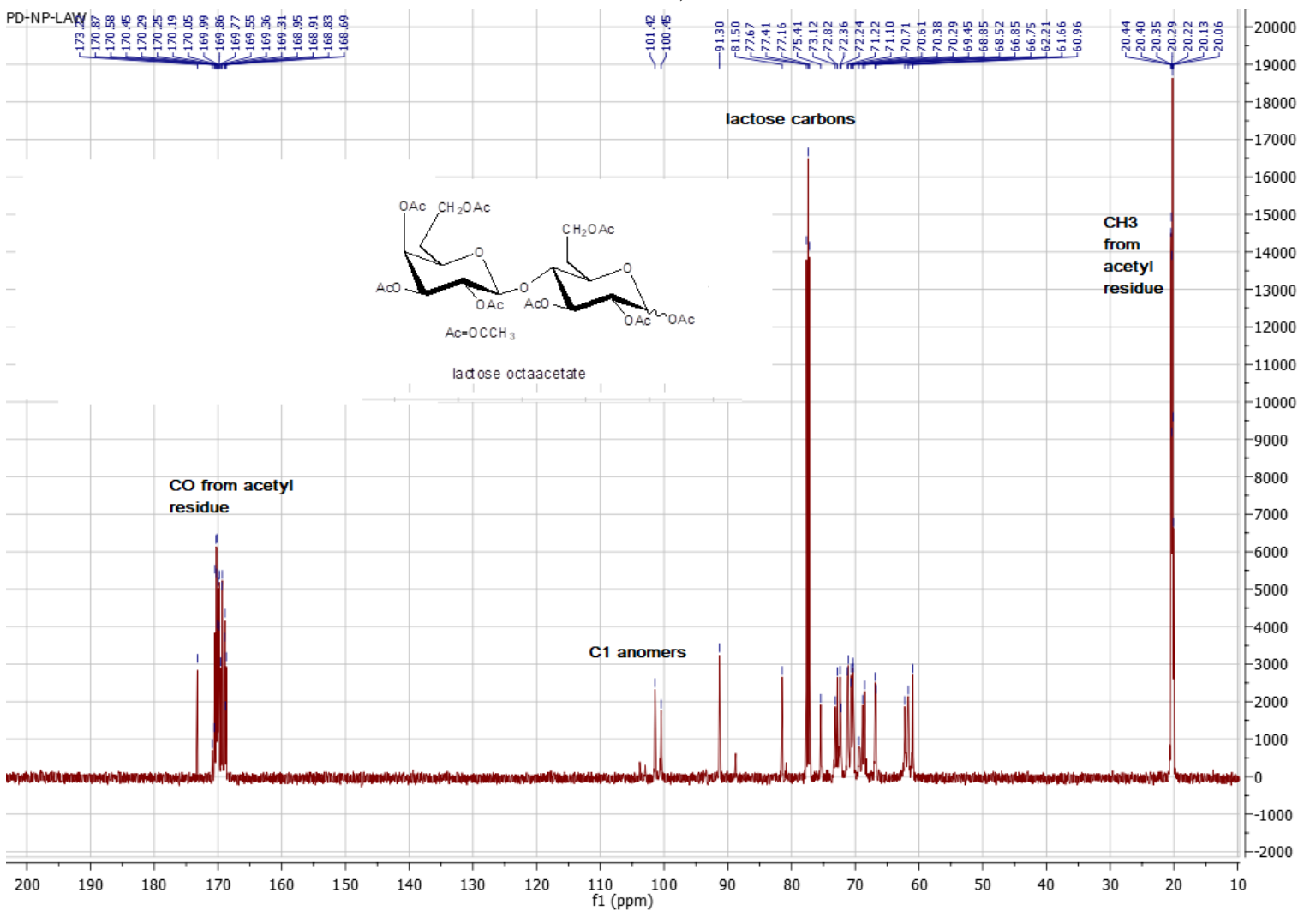

b)

Figure 4. (a) ${ }^{1} \mathrm{H}$ NMR and (b) ${ }^{13} \mathrm{C}$ NMR spectra of octa-O-acetyl-D-lactose synthesized by microwave irradiation. 


\subsubsection{WHC and OHC.}

Water holding and oil holding properties caused an effect on functional and sensory properties. Therefore, these features enlarge the application of modified carbohydrates in different industries. Until now, many studies about the evaluation of WHC and OHC of lactose octaacetates were not provided, and there is the absence of information about these functional properties. . Petkova et al. [29] investigated the influence of acetylation of FOSs with different DP and found that brought about the increase of their OHC. The OHC of lactose acetate was higher than their WHC and reached $3.4 \mathrm{~g}$ oil/g sample (Figure 5). Functional properties of lactose esters were compared with $\beta$-D-glucose pentaacetates (Figure 5).

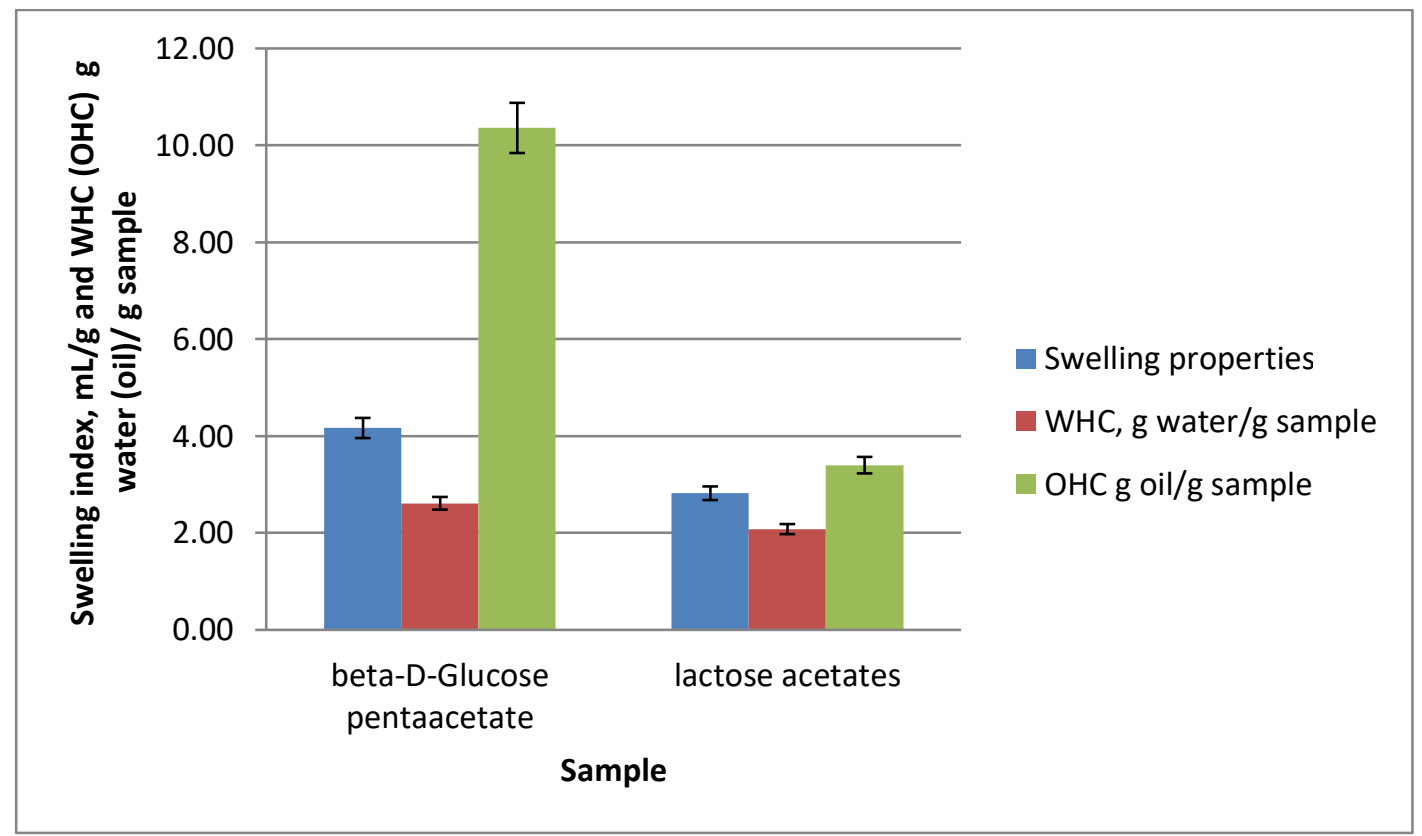

Figure 5. Swelling properties, water holding, and oil holding capacity of lactose acetate (LA 1) synthesized under microwave irradiation.

Lactose acetates and $\beta$-D-glucose pentaacetates demonstrated similar small values of WHC that did not exceed $2.5 \mathrm{~g}$ water/g sample. However, $\beta$-D-glucose pentaacetates retained three times more oil than lactose esters (Figure 5). OHC of lactose acetates was near that of inulin and starch acetates $[10,39]$. The higher values of $\mathrm{OHC}$ in acetylated carbohydrates could be explained with more acetylated residues. The complete substitution of hydrophilic $\mathrm{OH}$ groups in the lactose backbone with acetyl residues explained these properties. It was demonstrated that acetylation improved the water and oil holding capacities as a result of the incorporation of acetyl groups on the starch molecules which led to better binding capacity [39]. In different starches, their water and oil absorption capacities increase with the increased acetic anhydride concentration in carbohydrate chains $[39,40]$. The current study dealing with the $\mathrm{OHC}$ of lactose acetates demonstrated their potential use in pharmaceutical and food formulations.

\subsubsection{Foaming properties of lactose acetates.}

The foaming properties of modified carbohydrates with the short and long-chained fatty acid ester were reported $[4,5,10,16,21,42]$. However, until now, any data for the potential of lactose acetates as a foaming agent were not available. FA values for lactose acetate at a concentration of $0.1 \%$ are $95 \%$. The FS of the obtained lactose acetates was estimated by 
measuring the foam height of 1-60 min (Figures 6). For the foam obtained with $0.1 \%$ lactose acetate, FS decreases by more than $80 \%$ for the first 5 minutes, while the reduction of the foam for the next 5 minutes is $20 \%$. In comparison, the FS of octa-O-acetylsucrose $(0.1 \mathrm{~g} / \mathrm{L})$ does not exceed 50-55\% in 30 minutes [4]. The results demonstrate the formation of lactose acetate foam with low stability (10-20\%) in the studied concentration $(0.1 \%)$. It was reported that the foam height drops with the increase of the fatty acid carbon number and the presence of diesters in the preparation [43]. Some long-chained raffinose esters at concentration $0.2 \% \mathrm{w} / \mathrm{w}$ showed superior foamability (78.11\%) [41] near to our results with lactose acetates. Some authors explained low foamability with the smallest alkyl moieties [41]. In our case, low foam stability could be explained because lactose acetates were polyesters and contained short-chain hydrophobic residues. The foams formed with lactose acetates were stable until $5 \mathrm{~min}$ at concentration $0.1 \%$. Additional experiments should be provided to test the influence of concentration on foam stability of lactose esters.

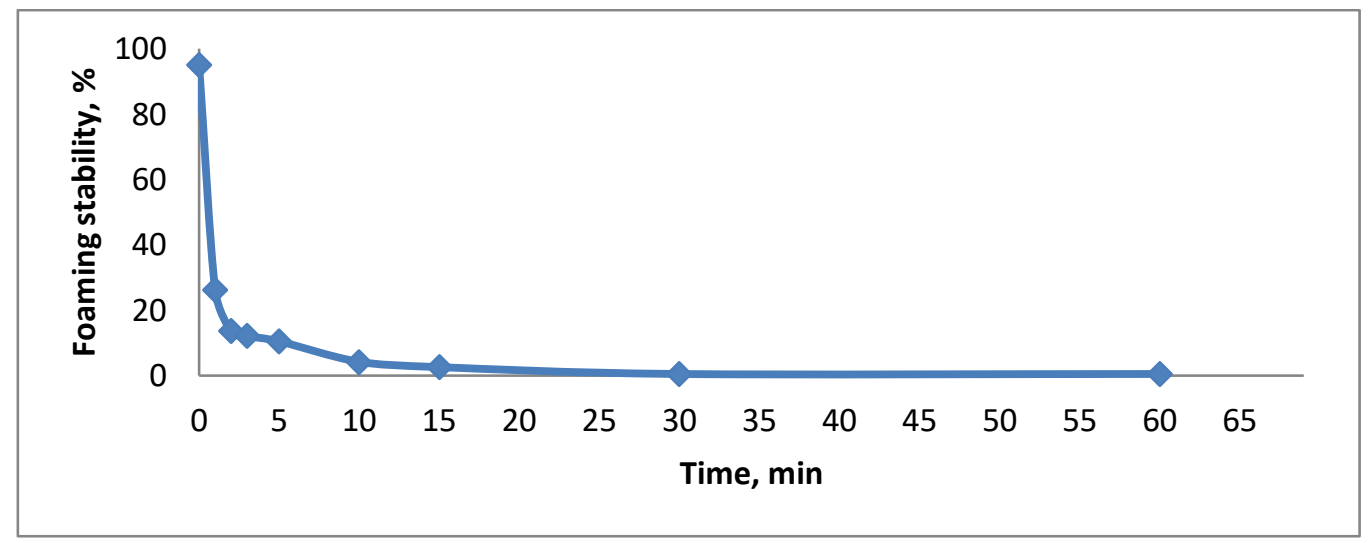

Figure 6. Foaming stability of lactose acetate (LA1).

\subsection{Antimicrobial activity.}

This study presents the first report for the antimicrobial activity of lactose acetates analyzed against twenty microorganisms. The results from the antimicrobial activity of lactose acetates (LA1) are summarized in Table 3. Its activity was comparable with the control antibiotic Nystatin $40 \mu \mathrm{g} / \mathrm{mL}$. From the obtained results, it was found that lactose acetates in the tested concentration did not inhibit the growth of Gram-positive and Gram-negative bacteria and yeasts. However, lactose acetylated esters possessed antifungal activity against Aspergillus niger ATCC 1015, Penicillium sp., Rhizopus sp., and Fusarium moniliforme ATCC 38932 (Table 3). Against Aspergillus flavus these esters were inactive. The obtained results found that lactose acetates showed moderate activity Rhizopus sp. and Fusarium moniliforme ATCC 38932. Compared to our previous research for sucrose octatacetates, lactose acetates demonstrated similar antimicrobial activity [4]. Similar to inulin acetates and inulin derivatives modified with Schiff bases [44], lactose acetates demonstrated mainly antifungal activity.

Table 3. Antimicrobial activity of lactose octaacetes (LA) expressed as the diameter of zones of inhibition in $\mathrm{mm}\left(\mathrm{d}_{\mathrm{disc}}=6 \mathrm{~mm}\right)$.

\begin{tabular}{|c|c|c|c|c|c|c|c|}
\hline \multirow[t]{2}{*}{ Test microorganism } & \multicolumn{2}{|c|}{ Lactose esters } & \multicolumn{2}{|c|}{ Solvents } & \multicolumn{3}{|c|}{ Positive controls } \\
\hline & $\begin{array}{l}\mathrm{LA} \mathrm{in} \\
\mathrm{MeOH}\end{array}$ & $\begin{array}{l}\text { LA in } \\
\text { DMSO }\end{array}$ & DMSO & $\begin{array}{l}\mathrm{MeO} \\
\mathrm{H}\end{array}$ & $\begin{array}{l}\text { Streptomycin } \\
30 \mu \mathrm{g} / \mathrm{mL}\end{array}$ & $\begin{array}{l}\text { Ampicillin } \\
10 \mathrm{mg} / \mathrm{mL}\end{array}$ & $\begin{array}{l}\text { Nystatin } \\
40 \mu \mathrm{g} / \mathrm{mL}\end{array}$ \\
\hline \multicolumn{8}{|l|}{ Gram (+) bacteria } \\
\hline B. subtilis ATCC 6633 & - & - & - & - & $28 * * *$ & 21 & $\mathrm{n} / \mathrm{a}$ \\
\hline B. cereus & - & - & - & - & $25 * * *$ & 40 & $\mathrm{n} / \mathrm{a}$ \\
\hline B. amyloliquefaciens strain & - & - & - & - & $24 * * *$ & 40 & $\mathrm{n} / \mathrm{a}$ \\
\hline
\end{tabular}




\begin{tabular}{|c|c|c|c|c|c|c|c|}
\hline \multirow[t]{2}{*}{ Test microorganism } & \multicolumn{2}{|c|}{ Lactose esters } & \multicolumn{2}{|l|}{ Solvents } & \multicolumn{3}{|c|}{ Positive controls } \\
\hline & $\begin{array}{l}\text { LA in } \\
\text { MeOH }\end{array}$ & $\begin{array}{l}\text { LA in } \\
\text { DMSO }\end{array}$ & DMSO & $\begin{array}{l}\mathrm{MeO} \\
\mathrm{H}\end{array}$ & $\begin{array}{l}\text { Streptomycin } \\
30 \mu \mathrm{g} / \mathrm{mL}\end{array}$ & $\begin{array}{l}\text { Ampicillin } \\
10 \mathrm{mg} / \mathrm{mL}\end{array}$ & $\begin{array}{l}\text { Nystatin } \\
\mathbf{4 0} \mu \mathrm{g} / \mathrm{mL}\end{array}$ \\
\hline \multicolumn{8}{|l|}{ 4BCL-YT } \\
\hline $\begin{array}{l}\text { S. aureus } \\
\text { ATCC } 25923\end{array}$ & - & - & - & - & $25 * * *$ & 40 & $\mathrm{n} / \mathrm{a}$ \\
\hline L. monocytogenes ATCC 8632 & - & - & - & - & $23 * * *$ & 33 & $\mathrm{n} / \mathrm{a}$ \\
\hline E. faecalis & - & - & - & - & $22 * * *$ & 38 & $\mathrm{n} / \mathrm{a}$ \\
\hline M. luteus strain 2YC-YT & - & - & - & - & $31 * * *$ & 40 & $\mathrm{n} / \mathrm{a}$ \\
\hline $\begin{array}{l}\text { C. flaccumfaciens strain PM- } \\
\text { YT }\end{array}$ & - & - & - & - & $35 * * *$ & 38 & $\mathrm{n} / \mathrm{a}$ \\
\hline \multicolumn{8}{|l|}{ Gram (-) bacteria } \\
\hline S. enteritidis & - & - & - & - & $18 * *$ & 38 & $\mathrm{n} / \mathrm{a}$ \\
\hline Klebsiella sp. & - & - & - & - & $18 * *$ & $14 * *$ & $\mathrm{n} / \mathrm{a}$ \\
\hline E. coli ATCC 8739 & - & - & - & - & $26 * * *$ & 40 & $\mathrm{n} / \mathrm{a}$ \\
\hline P. vulgaris ATCC 6380 & - & - & - & - & $24 * * *$ & 38 & $\mathrm{n} / \mathrm{a}$ \\
\hline Ps. aeruginosa ATCC 9027 & - & - & - & - & $23 * * *$ & - & $\mathrm{n} / \mathrm{a}$ \\
\hline \multicolumn{8}{|l|}{ Yeasts } \\
\hline C. albicans NBIMCC 74 & - & - & - & - & $\mathrm{n} / \mathrm{a}$ & $\mathrm{n} / \mathrm{a}$ & $13 * *$ \\
\hline S. cerevisiae & - & - & - & - & $\mathrm{n} / \mathrm{a}$ & $\mathrm{n} / \mathrm{a}$ & - \\
\hline \multicolumn{8}{|l|}{ Fungi } \\
\hline A. niger ATCC 1015 & $10 *$ & $10^{*}$ & - & - & $\mathrm{n} / \mathrm{a}$ & $\mathrm{n} / \mathrm{a}$ & - \\
\hline A. flavus & - & - & - & - & $\mathrm{n} / \mathrm{a}$ & $\mathrm{n} / \mathrm{a}$ & $8 *$ \\
\hline Penicillium sp. & $10^{*}$ & $10^{*}$ & - & - & $\mathrm{n} / \mathrm{a}$ & $\mathrm{n} / \mathrm{a}$ & $9 *$ \\
\hline Rhizopus sp. & $10 *$ & $15 * *$ & - & - & $\mathrm{n} / \mathrm{a}$ & $\mathrm{n} / \mathrm{a}$ & $10^{*}$ \\
\hline F. moniliforme ATCC 38932 & $10^{*}$ & $10^{*}$ & - & - & $\mathrm{n} / \mathrm{a}$ & $\mathrm{n} / \mathrm{a}$ & - \\
\hline
\end{tabular}

Moreover, acetylated saccharides with pyranose structures have higher antimicrobial and antifungal activities than acetylated saccharides with furanose structures [20]. In comparison to other lactose derivatives, it was demonstrated that O- $\beta$-D-galactopyranosyl$(1 \rightarrow 4)$-N-alkyl-(3-sulfopropyl)-D-glucosamine hydrochloride demonstrated antibacterial and fungistatic activity (Staphylococcus aureus, Bacillus subtilis, Escherichia coli, and Pseudomonas aeruginosa), yeasts (Candida albicans) and filamentous fungi (Fusarium graminearum, F. avenaceum, F. oxysporum, F. culmorum, F. equiseti, Alternaria alternata and Botrytis cinerea) [42]. It was reported that some lactose esters with long-chain fatty acids as lactose palmitoleate and lactose nervonate showed antimicrobial activity versus eight pathogenic species belonging to Gram-positive, Gram-negative microorganisms, and fungi [45]. It was demonstrated that lactose esters esterified with saturated fatty acid as decanoic and lauric acids showed greater antimicrobial properties than lactose esters of octanoate and myristate against Gram-positive bacteria [46]. In our case, lactose ocatacetates were inactive against Gram-positive, Gram-negative, and yeast but demonstrated antifungal activity.

\subsection{Cytotoxicity and antiviral effect of lactose acetates.}

Until now, any information about cytotoxicity and antiviral activity of lactose acetate was not found. Research deals with unsaturated fatty acid esters with lactose that revealed its cytotoxicity characterizations, their permeability enhancing activity was demonstrated using intestinal Caco-2 monolayer through transepithelial electrical resistance (TEER) and permeability [45]. Antiviral activity against some of the studies viruses was reported for polysaccharides - carrageenans [47]. Therefore, this is the first detailed study for cytotoxicity and antiviral activity of lactose octaacetates.

The cytotoxicity of synthesized lactose acetate was determined by three cell lines, MDBK, MDCK, and HEp-2, which are then the basis for conducting antiviral experiments (Table 4). The results showed the lowest toxicity of lactose acetates on the MDBK cell line and 
close cytotoxicity in Hep-2, whereas, in the MDCK cells, it demonstrates more than twice higher toxicity. Testing the antiviral activity of synthesized lactose acetate revealed inhibition of replication of PV-1 with a selective index of 2.4, but it was not found any specific antiviral effect against CVB1, HSV-1, and IAV/H3N2 replication (Table 4).

Table 4. Cytotoxic and antiviral activity of lactose acetates.

\begin{tabular}{l|l|l|l|l}
\multirow{2}{*}{ Cells and Viruses } & Cytotoxicity $(\boldsymbol{\mu g} / \mathbf{m L})$ & Antiviral activity & \multicolumn{2}{l}{ SI } \\
\cline { 2 - 5 } & CC50 & MTC & IC50 $(\boldsymbol{\mu g} / \mathbf{m L})$ & - \\
\hline Hep-2 & 533 & 250 & - & - \\
\hline MDCK & 688 & 200 & - & - \\
\hline MDBK & 1100 & 100 & - & 2.4 \\
\hline PV-1 & - & - & 215 & - \\
\hline CVB1 & - & - & - & - \\
\hline HSV-1 & - & - & - & -
\end{tabular}

The invested lactose octaacetate also showed antiviral activity against extracellular virions of HSV-1 virions. The effect was the strongest one (Table 5) in the HSV-1 virions, with the effect still accounting for $15 \mathrm{~min}$ of exposure $(\Delta \log =1.25)$ maintained with this value until $60 \min (\Delta \log =1.5)$.

Table 5. The viricidal activity of lactose acetate on HSV-1 virions.

\begin{tabular}{l|l|l|l|l}
\multicolumn{5}{l}{$\Delta \log$} \\
\hline $\mathbf{1 5}$ min & $\mathbf{3 0}$ min & $\mathbf{6 0}$ min & $\mathbf{9 0}$ min & $\mathbf{1 2 0}$ min \\
\hline 1.25 & 1.25 & 1.50 & 1.50 & 1.50
\end{tabular}

After determining the effect of lactose acetate on extracellular virions and replication of intracellular viruses, its further effect was monitored on the stage of adsorption of the virus to the respective sensitive cells. The adsorption inhibition on all three viruses occurred with approximately the same decrease in viral titers. At $15 \mathrm{~min}$ the effect was weak in all three viruses; at $30 \mathrm{~min}$ it became significant in HSV-1 $(\Delta \log =1.25)$, while in the other two viruses, it still had relatively low values, and after $45 \mathrm{~min}$ the adsorption of all three viruses was significantly suppressed, with the strongest effect observed at SVB1 at $60 \min (\Delta \log =1.4)$ (Table 6).

Table 6. Effect of lactose acetates on the viral adsorption.

\begin{tabular}{l|c|c|c|c}
\multirow{2}{*}{ Virus } & \multicolumn{4}{|c}{$\Delta \mathbf{l o g}$} \\
\cline { 2 - 5 } & $\mathbf{1 5} \mathbf{~ m i n}$ & $\mathbf{3 0} \mathbf{~ m i n}$ & $\mathbf{4 5} \mathbf{~ m i n}$ & $\mathbf{6 0} \mathbf{~ m i n}$ \\
\hline HSV-1 & 1.25 & 1.25 & 2.75 & 2.75 \\
\hline PV-1 & 1.0 & 1.0 & 2.0 & 2.0 \\
\hline CVB1 & 0.0 & 0.4 & 1.0 & 1.4
\end{tabular}

The protective effect of lactose acetates was also examined for virus-free cells and to evaluate their activity to which it could protect cells from viral invasion. The model to use MDBK cells was selected due to the fact that lactose acetates showed the lowest cytotoxicity. The cells treated with the lactose acetates had a significant decrease in infectious viral titers. At the first studied time interval - $15 \mathrm{~min}$, this decrease was with $\Delta \log =1.5$ and remained with such a value for up to 120 minutes (Table 7).

Table 7. Protective effect of lactose acetate on uninfected cells with subsequent herpes infection.

\begin{tabular}{c|c|c|c|c}
\multicolumn{5}{c}{$\Delta \mathbf{l o g}$} \\
\hline $\mathbf{1 5} \mathbf{~ m i n}$ & $\mathbf{3 0} \mathbf{~ m i n}$ & $\mathbf{6 0} \mathbf{~ m i n}$ & $\mathbf{9 0} \mathbf{~ m i n}$ & $\mathbf{1 2 0} \mathbf{~ m i n}$ \\
\hline 1.5 & 1.5 & 1.5 & 1.5 & 2.75
\end{tabular}




\section{Conclusions}

This research showed the efficiency of microwave irradiation for rapid and effective synthesis of lactose acetates with acetic anhydride, sodium acetate and the lack of solvent media only for $10 \mathrm{~min}-20 \mathrm{~min}$. The structure of the resulting esters was confirmed by FT-IR and NMR studies. To the best of our knowledge, the antimicrobial and antiviral activity of lactose esters was evaluated. Their antifungal potential against some plant and food-borne pathogens was demonstrated, as well as their functional properties. As a result of its cytotoxicity, antiviral and antifungal activities, lactose esters should be successfully applied for cosmetic purposes.

\section{Funding}

This research received no external funding.

\section{Acknowledgments}

We are grateful to Nevena Petkova and Nikola Burdjiev (University "St. Kliment Ohridski", Sofia, Bulgaria) for technical support for NMR studies.

\section{Conflicts of Interest}

The authors declare no conflict of interest.

\section{References}

1. Anastas, P.T. Green chemistry and the role of analytical methodology development. Crit Rev Anal Chem. 1999, 29, 167-175, https://doi.org/10.1080/10408349891199356.

2. Collins, J.; Leadbeater N. Microwave energy: a versatile tool for the biosciences. Org. Biomol. Chem. 2007, 5, 1141-1150, https://doi.org/10.1039/B617084F.

3. Fumio, T. Solid State Organic Chemistry: Efficient Reactions, Remarkable Yields, and Stereoselectivity. Acc. Chem. Res. 1995, 28, 480-486, https://doi.org/10.1021/ar00060a003.

4. Petkova, N.; Vassilev, D.; Grudeva, R.; Tumbarski, Y.; Vasileva, I.; Koleva, M.; Denev, P. "Green" Synthesis of Sucrose Octaacetate and Characterization of Its Physicochemical Properties and Antimicrobial Activity. Chem Biochem Eng Q. 2017, 31, 395-402, http://dx.doi.org/10.15255/CABEQ.2017.1117.

5. Huang, D.; Jiang, X.; Zhu, H.; Fu, X.; Zhong, K.; Gao, W. Improved synthesis of sucrose fatty acid monoesters under ultrasonic irradiation. Ultrason. Sonochem. 2010, 17, 352-355, https://doi.org/10.1016/j.ultsonch.2009.08.009.

6. Vassilev, D.; Petkova, N.; Koleva, M.; Denev, P. Optimization of ultrasound synthesis of sucrose esters by selection of a suitable catalyst and reaction conditions. J. Chem. Technol and Metall. 2021, 56, 268-274.

7. Petkova, N.; Arabadzhieva, R.; Hambarliyska, I.; Vassilev, D.; Gencheva, G.; Tumbarski, Y.; IgnatovaIvanova, T.: Ibryamova, S.; Koleva M.; Denev, P. Ultrasound-Assisted Synthesis of Antimicrobial Inulin and Sucrose Esters with 10-Undecylenic Acid. Biointerface Res. Appl. Chem. 2021, 11, 12055-12067, https://doi.org/110.33263/BRIAC114.1205512067.

8. Matin, M.M.; Bhattacharjee, S.C.; Chakraborty, P.; Alam, M.S. Synthesis, PASS predication, in vitro antimicrobial evaluation and pharmacokinetic study of novel n-octyl glucopyranoside esters. Carbohydr. Res. 2019, 485, 107812, https://doi.org/10.1016/j.carres.2019.107812.

9. Calce, E.; Petricci, E.; Saviano, M.; De Luca, S. Green microwave-assisted procedure to generate bio-based pectin materials. Sustain. Chem. Pharm. 2017, 5, 127-130, https://doi.org/10.1016/j.scp.2016.09.002.

10. Petkova, N.; Arabadzhieva, R.; Vassilev D.; Gencheva, G.; Tumbarski, Y.; Ignatova-Ivanova, T.; Ibryamova, S.; Todorova, M.; Koleva, M.; Denev P. Physicochemical characterization and antimicrobial properties of inulin acetate obtained by microwave-assisted synthesis. J. Renew. Mater. 2020, 8, 365-381, https://www.techscience.com/jrm/v8n4/38710. 
11. Sardo, C.; Craparo E.F.; Fiorica, C.; Giammona, G.; Cavallaro, G. Inulin derivatives obtained via enhanced microwave synthesis for nucleic acid based drug delivery. Curr Drug Targets 2015, 16, 1650-1659, https://doi.org/10.2174/138945011614151119130426.

12. Ravichandran, S.; Karthikeyan, E. Microwave Synthesis - A Potential Tool for Green Chemistry. Int. J. Chemtech Res. 2011, 1, 466-470.

13. Rana, K.; Rana, S. Microwave Reactors: A Brief Review on Its Fundamental Aspects and Applications. Open Access Library Journal 2014, 1, e686, https://doi.org/10.4236/oalib.1100686.

14. Tsuji, M.; Hashimoto, M.; Nishizawa, Y.; Kubokawa, M.; Tsuji, T. Microwave-Assisted Synthesis of Metallic Nanostructures in Solution. Chem. A Eur. J. 2005, 11, 440-451, https://doi.org/10.1002/chem.200400417.

15. Teng, Y.; Stewart, S.G.; Hai, Y.W.; Li, X.; Banwell, M.G.; Lan, P. Sucrose fatty acid esters: synthesis, emulsifying capacities, biological activities and structure-property profiles. Crit Rev Food Sci Nutr. 2021, 61, 3297-3317, https://doi.org/10.1080/10408398.2020.1798346.

16. Enayati, M.; Gong, Y.; Goddard, J.M.; Abbaspourrad, A. Synthesis and characterization of lactose fatty acid ester biosurfactants using free and immobilized lipases in organic solvents. Food Chem. 2018, 266, 508-513, https://doi.org/10.1016/j.foodchem.2018.06.051.

17. McNaught, A. Nomenclature of carbohydrates. Carbohydr. Res. 1997, 297, 1-92, https://doi.org/10.1016/S0008-6215(97)83449-0.

18. Patil, B.; Babu, V. A rapid and convenient synthesis of $\alpha$ and $\beta$ forms of acetylated derivatives of sugars under microwave irradiation. NISCAIR Online Periodicals Repository 2004, 43B, 1288-1291, http://nopr.niscair.res.in/handle/123456789/18776.

19. Peng, X.; Jacqueline Y.; Pavol, K. Observations on the Preparation of $\beta$-Lactose Octaacetate. J. Carbohydr. Chem. 2012, 31, 711-720, https://doi.org/10.1080/07328303.2012.739230.

20. Matin, M.M.; Bhuiyan, M.M.H.; Afrin, A.; Debnath, C.D. Comparative antimicrobial activities of some monosaccharide and disaccharide acetates. J. Sci. Res. 2013, 5, 515-525, https://dx.doi.org/10.3329/jsr.v5i3.15695.

21. Jabbari, H. Synthesis of carbohydrate esters and investigation reaction of Phosphoryl chloride from anomeric position of per-acetylated carbohydrates. Arch. Pharm. Pract. 2020, 1, 71-75, https://archivepp.com/article/synthesis-of-carbohydrate-esters-and-investigation-reaction-of-phosphorylchloride-from-anomeric-position-of-per-acetylated-carbohydrates.

22. Staroń, J.; Dąbrowski, J.M.; Cichoń, E.; Guzik, M.W. Lactose esters: synthesis and biotechnological applications. Crit. Rev. Biotechnol. 2018, 38, 245-258, https://doi.org/10.1080/07388551.2017.1332571.

23. Sodhi, N.; Singh N. Characteristics of acetylated starches prepared using starches separated from different rice cultivars. J. Food Eng. 2005, 70, 117-127, https://doi.org/10.1016/j.jfoodeng.2004.09.018.

24. Rajput, J.; Hotha, S.; Vangala, M. AuBr3-catalyzed azidation of per-O-acetylated and per-O-benzoylated sugars. Beilstein J Org Chem. 2018, 14, 682-687, https://doi.org/10.3762/bjoc.14.56.

25. Šardzík, R.; Noble, G.T.; Weissenborn, M.J.; Martin, A.; Webb, S.J.; Flitsch, S.L. Preparation of aminoethyl glycosides for glycoconjugation. Beilstein J Org Chem. 2010, 6, 699-703, https://doi.org/10.3762/bjoc.6.81.

26. Raku, T.; Kitagawa, M.; Shimakawa, H.; Tokiwa, Y. Enzymatic synthesis of hydrophilic undecylenic acid sugar esters and their biodegradability. Biotechnol. Lett. 2003, 25, 161-166, https://doi.org/10.1023/A:1021983705883.

27. Llanes, L.; Dubessay, P.; Pierre, G.; Delattre, C.; Michaud, P. Biosourced polysaccharide-based superabsorbents. Polysaccharides 2020, 1, 51-79, https://doi.org/10.3390/polysaccharides1010005.

28. Holloway, W.D.; Greig, R. I. Water holding capacity of hemicelluloses from fruits, vegetables and wheat bran. J. Food Sci. 1984, 49, 1632-1633, https://doi.org/10.1111/j.1365-2621.1984.tb12867.x.

29. Petkova, N.T.; Arabadzhieva, R.D.; Tumbarski, Y.D.; Todorova, M.M.; Hambarlyiska, I.P.; Ivanov, I.G.; Ignatova-Ivanova, T.V. Physicochemical properties and antimicrobial activity of acetylated chicory $\begin{array}{llllll}\text { fructooligosaccharides. Philipp } & J & S c i & \mathbf{2 0 2 1}, & \text { 150, }\end{array}$ https://philjournalsci.dost.gov.ph/images/pdf/pjs_pdf/vol150no3/physicochemical_properties_and_antimicr obial_activity_of_ACF_.pdf.

30. Tumbarski, Y.; Lincheva, V.; Petkova, N.; Nikolova, R.; Vrancheva, R.; Ivanov I.. Antimicrobial activity of extract from aerial parts of potentilla (Potentilla reptans L.). Indust. Technol. 2017, 4, 37-43.

31. Vilhelmova-Ilieva, N.; Dobreva, A.; Doynovska, R.; Krastev, D.; Mileva, M. Antiviral activity of Rosa damascena Mill. And Rosa alba L. essential oils against the multiplication of herpes simplex virus type 1 strains sensitive and resistant to Acyclovir. Biology 2021, 10, 746, https://doi.org/10.3390/biology10080746. 
32. Smutzer, G.; Cherian, S.; Patel, D.; Lee, B.S.; Lee, K.; Sotelo, A.R.; Mitchell, K.D.W. A formulation for suppressing bitter taste in the human oral cavity. Physiol. \& Behav. 2020, 226, 113129, https://doi.org/10.1016/j.physbeh.2020.113129.

33. Malaisse, W.J.; Malaisse-Lagae, F. Bitter taste of monosaccharide pentaacetate esters. IUBMB Life 1997, 43, 1367-1371, https://doi.org/10.1080/15216549700205181.

34. Stagner, W.C.; Gaddam, S.; Parmar, R.; Ghanta, A.K. Sucrose octaacetate. In: Profiles of Drug Substances, Excipients and Related Methodology 2019, 44, 267-291, Brittain, H.G. (Ed.), Academic Press, https://doi.org/10.1016/bs.podrm.2019.02.002.

35. Hutchings, M.; Bamfiel, P. Chromic phenomena: technological applications of colour chemistry 2010, 1584, 3-rd edition, Royal Society of Chemistry, https://doi.org/10.1039/9781849731034.

36. Kleiman, M.; Ryu, K.A.; Esser-Kahn, A.P. Determination of factors influencing the wet etching of polydimethylsiloxane using tetra-n-butylammonium fluoride. Macromol Chem Phys. 2016, 217, 284-291, https://doi.org/10.1002/macp.201500225.

37. Wiercigroch, E.; Szafraniec, E.; Czamara, K.; Pacia, M.Z., Majzner, K.; Kochan, K.; Kaczor, A.; Baranska, M.; Malek, K. Raman and infrared spectroscopy of carbohydrates: A review. Spectrochim. Acta Part A: Mol. Biomol. Spectrosc. 2017, 185, 317-335, https://doi.org/10.1016/j.saa.2017.05.045.

38. Buzatu, A.R.; Frissen, A.E.; van den Broek, L.A.M.; Todea, A.; Motoc, M.; Boeriu, C.G. Chemoenzymatic synthesis of new aromatic esters of mono- and oligosaccharides. Processes 2020, 8, 1638, https://doi.org/10.3390/pr8121638.

39. Rahim, A.; Hutomo, G.S.; Rahman, N.; Bohari; Abdul Halid, S. Structure and functional properties of Arenga starch by acetylation with different concentrations of acetic anhydride. Asian J. Sci. Res. 2019, 12, 220-228, https://doi.org/10.3923/ajsr.2019.220.228.

40. Oderinde, A.A.; Ibikunle, A.A.; Bakre, L.G.; Babarinde, N.A.A. Modification of African breadfruit (Treculia africana, Decne) kernel starch: Physicochemical, morphological, pasting, and thermal properties. Int. J. Biol. Macromol. 2020, 153, 79-87, https://doi.org/10.1016/j.ijbiomac.2020.02.293.

41. Li, X.; Hai, Y. W.; Ma, D.; Chen, J.; Banwell, M.G.; Lan, P. Fatty acid ester surfactants derived from raffinose: Synthesis, characterization and structure-property profiles. J. Colloid Interface Sci. 2019, 556, 616627, https://doi.org/10.1016/j.jcis.2019.08.070.

42. Michocka, K.; Staszak, K.; Gwiazdowska, D.; Wieczorek, D. Synthesis, surface and antimicrobial activity of new lactose-based surfactants. Molecules. 2019, 24, 4010, https://doi.org/10.3390/molecules24214010.

43. Soultani, S.; Ognier, S.; Engasser, J.-M.; Ghoul, M. Comparative study of some surface active properties of fructose esters and commercial sucrose esters. Colloids Surf A: Physicochem Eng Asp. 2003, 227, 35-44, https://doi.org/10.1016/S0927-7757(03)00360-1.

44. Chen, Y.; Mi, Y.; Sun, X.; Zhang, J.; Li, Q.; Ji, N.; Guo, Z. Novel Inulin derivatives modified with Schiff bases: synthesis, characterization, and antifungal activity. Polymers 2019, 11, 998, https://doi.org/10.3390/polym11060998.

45. Lucarini, S.; L. Fagioli, L.; Campana, R.; Cole, H.; Duranti, A.; Baffone, W.; Vllasaliu, D.; Casettari, L. Unsaturated fatty acids lactose esters: cytotoxicity, permeability enhancement and antimicrobial activity. Eur J Pharm Biopharm. 2016, 107, 88-96, https://doi.org/10.1016/j.ejpb.2016.06.022.

46. Lee, S.M.; Sandhu, G.; Walsh, M.K. Growth inhibitory properties of lactose fatty acid esters. Saudi J. Biol. Sci. 2017, 24, 1483-1488, https://doi.org/10.1016/j.sjbs.2015.10.013.

47. Álvarez-Viñas, M.; Souto, S.; Flórez-Fernández, N.; Torres, M.D.; Bandín, I.; Domínguez, H. Antiviral activity of carrageenans and processing implications. Mar. Drugs 2021, 19, 437, https://doi.org/10.3390/md19080437. 